\title{
Predictive Analysis of the Effect of Tillage System on the Growth and Yield of Rice Plant under Lowland Plantation
}

\author{
${ }^{1}$ C.O. Aremu, ${ }^{2}$ T.A. Olayanju, ${ }^{2}$ E.A. Alhassan, ${ }^{1}$ Ojo Adebiyi, ${ }^{1}$ Stephen Abolusoro, \\ ${ }^{3}$ Henry Inegbedion, ${ }^{4}$ A. J. Asaleye, ${ }^{5}$ Ademiluyi Segun, ${ }^{6}$ Ake Modupe \\ ${ }^{1}$ Department of Crop Science, \\ ${ }^{2}$ Department of Agricultural and Biosystems Engineering, \\ ${ }^{3}$ Department of Business Administration, \\ ${ }^{4}$ Department of Economics, Landmark University, P.M.B 1001, Omu-Aran, Nigeria \\ ${ }^{5}$ National Center for Agricultural Mechanization (NCAM), Ilorin, Nigeria \\ ${ }^{6}$ Department of Political Science and International Relation, Landmark University, \\ P.M.B 1001, Omu-Aran, Nigeria
}

\begin{abstract}
Empirical data and analysis of the effect of tillage techniques on the growth and yield of three varieties of rice under lowland farming were undertaken. Soil samples were taken up to a depth of $21 \mathrm{~cm}$ to obtain the soil characteristics and textural classification of the experimental site. The experimental data obtained were based on three varieties of rice namely FARO 52, FARO 44 and local rice type under three field preparation methods-no tillage flat field (A), tillage with shanti hydropower power tiller (China technology Model DF-121) (B) and tillage with Sawah eco-technology rice farming (serif) (Indonesian technology Quick G1000 Boxer) (C)). Requisite data gathered during the rice developmental stages such as days to flowering, days to maturity, number of tillers, panicle length, plant height and grain yield were statistically analysed to obtain predictive equations of the effect of the tillage techniques on the growth and yield of the rice varieties investigated. The soil analysis of the experimental site showed a sandy loam using USDA textural classification and the predictive results obtained showed a linear relationship between the investigated parameters. The research outcome can be a viable tool for future prediction of the effect of tillage techniques on the agronomic and yield characteristics of rice under lowland plantation.
\end{abstract}

Key words: Rice variety, lowland plantation, tillage techniques, developmental characteristics, predictive tools, sandy loam

\section{INTRODUCTION}

Rice (Oriza sativa L.) is a monocotyledonous cereal crop belonging to the Gramineae group (Ajala and Gana, 2015). Rice is a staple food crop with wide acceptability in Nigeria and many other parts of the world because of the importance attached to it both at the family cycle and social events. The demands for it have been on the increase over the year with demand exceeding the current local production in Nigeria. Importation mostly from Asia of the deficit has been undertaken in order to meet the demand of this essential food materials by the teeming population (Olaye et al., 2016; Merem et al., 2017). Analysis of the nutritive properties of rice revealed a rich food substance constituting about $23 \%$ of human per capita energy and $16 \%$ of per capita protein (Kemi, 2018). The government of Nigeria has made significant efforts at making the country self-sufficient in rice production for her populace. There have been the adoption of modern technology in rice farming and the training of personnel in the use of these technologies. The performance of these technologies varies because of factors relating to the weather condition, crop and soil types. An investigation into the effect of this technology on the growth and yield of rice using a predictive approach is necessary for future study and inferences relating to this area of knowledge.

Predictive equations are mathematical representation of conception of a system or a set of equations which represent the behaviour of a system with the purpose of aiding, understanding and improving the performance of the system (Patricia et al., 2007). Researchers have used these techniques for predicting crop yields. Problems relating to biology, ecology and environment have been solved using set of mathematical equations. These have helped to predict system output, classify data and

Corresponding Author: E.A. Alhassan, Department of Agricultural and Biosystem Engineering, Landmark University, P.M.B 1001, Omu-Aran, Nigeria 
understand processes (Adekalu and Okunade, 2008; Safa, 2011). The application of simulation models in agriculture is rapidly increasing and gaining acceptability (Adekalu and Okunade, 2008; El-Sharkawy, 2011). Many of these applications have become useful tools that characterize and estimate yield under different levels of available water. Various models are now being used to gain better insight into the design and management of irrigation and drainage systems, irrigation scheduling and water use and the environmental monitoring of pollutants in the soil-water network (Adekalu and Okunade, 2008). Modeling that aid decision making in sustainable agriculture does not necessarily require the description of all elements in fine detail, the approach needs to be tailored for the purpose. Relatively, simple descriptions of specific processes are sufficient if the processes are known to respond to a limited subset of external conditions or if other unmodeled effects can be solved through appropriate adjustments to accommodate errors (Oladapo and Omidiora, 2014). The need to provide a logical procedure for predicting process output in conditions other than those that have been observed is the focus of this research.

Yield crop modeling can also be useful as a means to help scientists define research priorities (Donohue et al., 2018). Using a model to estimate the importance and the effect of certain parameters, a researcher can observe which factors should be more investigated in future research, thus, increasing the understanding of the system (Donohue et al., 2018). Crop Simulation Models (CSM) are computerized representations of crop growth, development and yield, simulated through mathematical equations as functions of soil conditions, inputs, weather and management practices (Gottschalk et al., 2018). These have played important roles in the interpretation of agronomic results and their application as decision support systems for farmers is increasing. The crop growth system, in general is more stochastic than deterministic because many parts of the agro-ecosystem are heterogeneous (Gottschalk et al., 2018).

Statistical models can provide many insights into past yields and historical influences and can be used to inform the other kinds of models (Ramirez-Villegas et al., 2017; Rowhani et al., 2011). Parametric linear models as a form of parametric regression are frequently used to describe the association between the dependent variable and the independent variables. They require the estimation of a finite number of parameters (Meshesha and Abeje, 2018).

\section{MATERIALS AND METHODS}

Experimental site description and research procedures: The experimental site is located at the Landmark
University teaching and research farm. It is on latitude $8.1239^{\circ} \mathrm{N}$ and longitude $5.0834^{\circ}$ in the North Central Region of Nigeria. The experimental layout is a $3 \times 3$ factorial design that was completely randomized. It involved three methods of tillage namely, no-tillage but flat field (A), tillage using Shanti hydropower tiller (B) and Serif technology (C). The field termed no tillage was prepared using hoes and shovel, the hydropower using China made Model DF-121 and the serif technology using Indonesian made Quick G1000 Boxer. Three varieties of paddy rice namely FARO 52, FARO 44 and local rice was raised in the nursery for 4 weeks to produce seedlings for transplanting. Using the two other tillage methods, basin sizes of dimension $3 \times 2 \mathrm{~m}$ were created. These were guarded by bunds to control water flow in and out of the basins (Gupta and Kumar, 2001). Each rice variety was transplanted after 4 weeks into the basin which is the plot size for the no-tillage, hydropower (shanti) and serif technology plot. This was replicated 3 times to give a total of 1350 plant stands (Aremu et al., 2018).

Collection of soil samples and experimental measurement: Soil samples were taken at random location up to a depth of $20 \mathrm{~cm}$ using a hand auger. Soil samples taken were kept in an airtight polythene bag and taken to the laboratory for analysis of the soil physicochemical properties following procedures described by Alhassan et al. (2018). Some of the physical and chemical parameters determined were texture, porosity, bulk density, moisture content, $\mathrm{pH}$, electrical conductivity, available phosphorus, available potassium, sodium, Cation Exchange Capacity (CEC), extract iron, copper, manganese and zinc, total nitrogen and carbon, organic matter, calcium, bacterial and fungal count.

Some agronomic characteristics such as days to flowering, days to maturity, number of tillers, panicle length, plant height and grain yield data were counted/measured. Measuring tape, visual counting and weighing scale were used for the data collection. IBM SPSS Statistics 22, Microsoft Excel and Minitab 17 statistical tools were used for the analysis of the collected data.

\section{RESULTS AND DISCUSSION}

Soil classification and physicochemical properties: The results of the soil samples taken up to a depth of $20 \mathrm{~cm}$ are as presented in Table 1. It revealed the descriptive statistics of obtained field data. The soil textural analysis shows a $4.32-8.32 \%$ of clay, $8.56-15.56 \%$ of silt and $78.12-86.12 \%$ of sand. The experimental site is a sandy loam soil based on USDA textural classification. The 
J. Eng. Applied Sci., 14 (10): 3422-3429, 2019

Table 1: Experimental soil analy sis results of the research field (Sampling depth: $0-20 \mathrm{~cm}$ )

\begin{tabular}{|c|c|c|c|c|c|c|c|}
\hline \multirow[b]{2}{*}{ Parameters } & \multicolumn{2}{|c|}{ Minimum } & \multicolumn{2}{|c|}{ Maximum } & \multirow[b]{2}{*}{ Mean $\pm \mathrm{SD}(\mathrm{N}=18)$} & \multirow{2}{*}{$\begin{array}{l}\text { Grid(s) with the } \\
\text { minimum values }\end{array}$} & \multirow{2}{*}{$\begin{array}{l}\text { Grid(s) with the } \\
\text { maximum values }\end{array}$} \\
\hline & Values & Ratings & Values & Ratings & & & \\
\hline Gravel (\%) & 25.40 & Low & 78.9 & High & $62.6 \pm 13.0$ & TR16 & TR15 \\
\hline Textural class & & Sand & & Sandy loam & & & \\
\hline Clay (\%) & 4.32 & 8.32 & & & $5.38 \pm 1.11$ & TR16 & TR9 \\
\hline Silt (\%) & 8.56 & 15.56 & & & $11.06 \pm 1.76$ & TR1, TR9 & TR8 \\
\hline Sand (\%) & 78.12 & 86.12 & & & $83.56 \pm 2.04$ & TR8 & TR12 \\
\hline pH (Water) & 5.90 & Mod. acid & 6.67 & Neutral & $6.30 \pm 0.2$ & TR14 & TR12 \\
\hline $\mathrm{pH}\left(0.01 \mathrm{M} \mathrm{CaCl}_{2}\right)$ & 5.24 & & 6.03 & & $5.70 \pm 0.3$ & TR1 & TR15 \\
\hline $\mathrm{pH}(1 \mathrm{M} \mathrm{KCl})$ & 5.19 & & 6.06 & & $5.50 \pm 0.2$ & TR2 & TR15 \\
\hline Tot. Nitrogen (\%) & 0.12 & Mod. low & 0.61 & Very high & $0.22 \pm 0.12$ & TR3 & TR6 \\
\hline Tot. Carbon (\%) & 1.00 & Low & 2.21 & Very high & $1.45 \pm 0.38$ & TR16 & TR15 \\
\hline $\mathrm{C}: \mathrm{N}$ & 1.80 & & 11.7 & & $7.60 \pm 2.2$ & TR6 & TR10 \\
\hline Avail P (mg P/kg) & 8.50 & Moderate & 36.7 & High & $15.10 \pm 7.0$ & TR16 & TR1 \\
\hline $\mathrm{Ca}^{2+}(\mathrm{cmol}(+) / \mathrm{kg})$ & 1.60 & Very low & 4.50 & Low & $2.90 \pm 0.7$ & TR16 & TR14, TR15 \\
\hline $\mathrm{Mg}^{2+}(\mathrm{cmol}(+) \mathrm{kg})$ & 3.80 & High & 9.20 & Very high & $5.1 \pm 1.2$ & TR8, TR14 & TR15 \\
\hline $\mathrm{K}^{+}(\mathrm{cmol}(+) / \mathrm{kg})$ & 0.25 & Low & 0.30 & Low & $0.28 \pm 0.02$ & TR8, 10,12 & Rest \\
\hline $\mathrm{Na}^{+}(\mathrm{cmol}(+) / \mathrm{kg})$ & 0.00 & Very low & 0.10 & Very low & $0.04 \pm 0.01$ & TR8 & TR6 \\
\hline $\mathrm{Al}+\mathrm{H}(\mathrm{cmol}(+) \mathrm{kg})$ & 0.00 & & 0.90 & & $0.34 \pm 0.31$ & TR1,4,6 & TR10 \\
\hline $\mathrm{CEC}(\mathrm{cmol}(+) / \mathrm{kg})$ & 7.20 & Low & 14.80 & Moderate & $8.60 \pm 1.7$ & TR1 & 14.8 \\
\hline Base saturation (\%) & 89.50 & Very high & 100.00 & Very high & $96.20 \pm 3.3$ & TR10 & TR4, 6,1 \\
\hline Extract $\mathrm{Fe}(\mathrm{mg} / \mathrm{kg})$ & 9.50 & & 23.40 & & $15.50 \pm 4.3$ & TR14, IRLS & TR16 \\
\hline Extract $\mathrm{Cu}(\mathrm{mg} / \mathrm{kg})$ & 28.10 & & 105.90 & & $72.00 \pm 24.0$ & IRMS & TR9 \\
\hline Extract $\mathrm{Mn}(\mathrm{mg} / \mathrm{kg})$ & 8.00 & & 41.30 & & $22.00 \pm 7.8$ & TR7 & TR14 \\
\hline Extract $\mathrm{Zn}(\mathrm{mg} / \mathrm{kg})$ & 3.30 & & 35.40 & & $15.30 \pm 0.1$ & IRLS & TR2 \\
\hline
\end{tabular}

Table 2: Tillage methods and effect on soil characteristics

\begin{tabular}{llll}
\hline Soil characteristics & Flat land (Non-tillage) & Tilled (Hydrolic P Tiller) & Tilled (Sawah Eco Techrif) \\
\hline $\begin{array}{l}\text { Soil pH } \\
\text { Organic matter }\end{array}$ & 6.30 & 5.60 & 5.90 \\
OC & 1.84 & & 0.97 \\
OM & 3.18 & 0.50 & 1.76 \\
Particle clay & & 0.87 & 4.95 \\
Clay (\%) & 6.32 & 4.3 & 10.53 \\
Silt $(\%)$ & 16.22 & 6.72 & 91.22 \\
Sand (\%) & 77.46 & 88.96 & 0.85 \\
Bulk density $\left(\mathrm{g} / \mathrm{cm}^{3}\right)$ & 1.049 & 0.64 & $18 \times 10^{5}$ \\
Bacteria count & $17 \times 10^{5}$ & $19 \times 10^{5}$ & $31 \times 10^{-2}$ \\
Fungal count & $3 \times 10^{-2}$ & $40 \times 10^{-2}$ & \\
\hline
\end{tabular}

required macro and microelements needed for the proper vegetative growth of the plant were also found to be adequate as analysed.

An investigation into the effect of the tillage technologies on the soil characteristics as studied is as presented in Table 2 .

According to Ingle et al. (2018), the most suitable $\mathrm{pH}$ range is $6.0-8.0$ for crop production. The experimental site has a $\mathrm{pH}$ range of 5.60-6.30 for the three tillage methods. This shows a favourable environment for activities required for healthy plant growth.

The plot with the non-tillage method had the highest bulk density. This may be due to the inability of the tillage technique to penetrate deep into the soil. It also has the highest quantity of organic matters because the level of soil pulverization and inversion is also small compared to the other two techniques that use mechanical power. The bacteria and fungi count are also the highest in the no-tillage method.
There is also variation in the textural properties of the soil based on the tillage techniques. This has an effect on the soil physicochemical properties as shown in Table 2.

Graphical representation of the effect of investigated parameters on rice agronomical characteristics: The surface and contour plots for the rice variety and the tillage treatment are as shown in Fig. 1. These plots show the interaction of the tillage techniques and plant agronomic characteristics as investigated.

Box plot representation of the effect of tillage techniques on the agronomic properties of rice varieties: Figure 2-7 shows the graphical representation of the effect of tillage systems on the growth and yield of the rice plant. These boxes also show the location of the first, second (median), third and fourth quartile distribution of each tillage systems effect on the various varieties. This location corresponds to the horizontal lines starting from the 

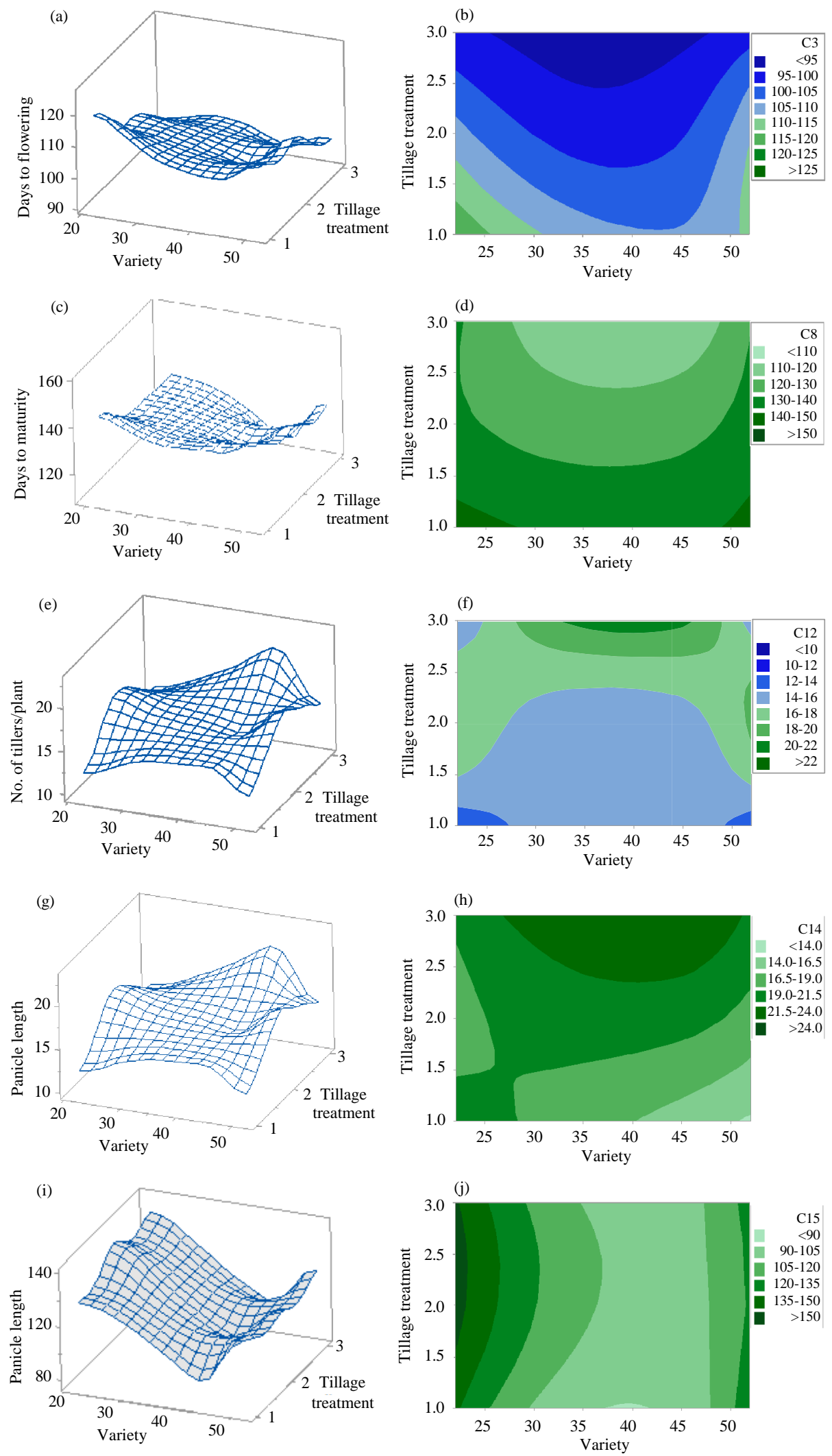

Fig. 1: Continue 

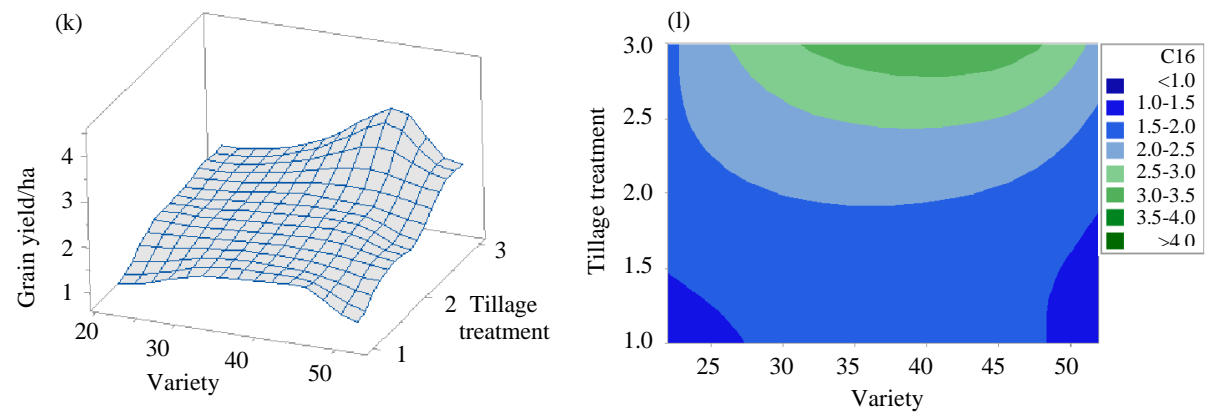

Fig. 1: Relationship between the 3 different rice varieties and tillage treatments on the developmental performance and yield of rice: a) Days to flowering; b) Days to flowering; c) Days to maturity; d) Contour plot of days to maturity; e) Surface plot for No. of tillers per plant; f) Contour plot of No. of tillers per plant; g) Surface plot of panicle length; h) Contour plot of panicle length; i) Surface plot of plant height; j) Contour plot of plant height; k) Surface plot of grain yield and 1) Contour plot of grain yield/ha

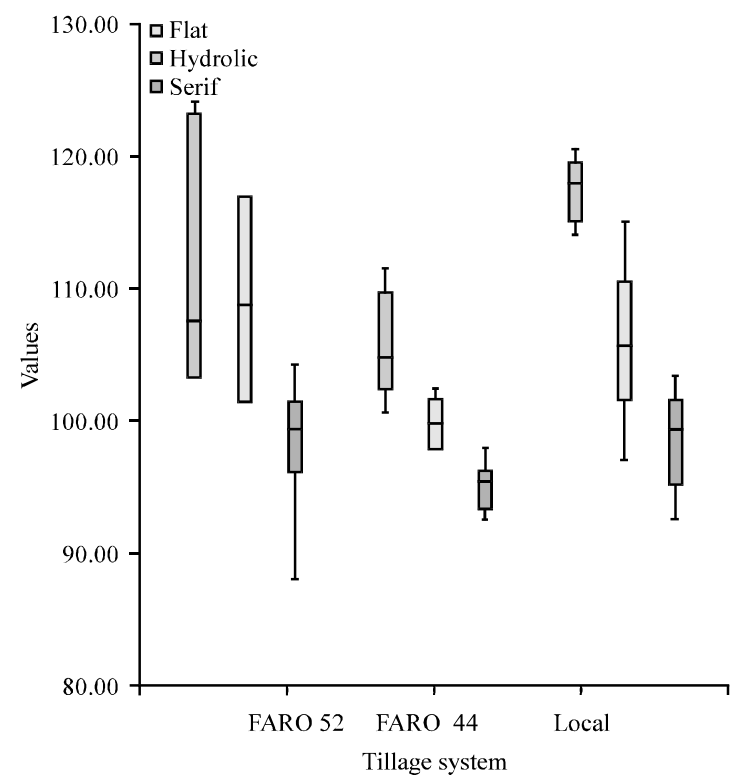

Fig. 2: Box plot of tillage systems effect on the days to flower of the three varieties of rice

baseline of the box to the top whisker with the thick line dividing the box as the second quartile (median). Overlapping boxes reflects a possible relationship between the three tillage techniques, especially, when the median line is almost on the same point on the y-axis.

Regression and correlation analysis of the investigated parameters: Table 3 revealed a linear relationship which is statistically significant between tillage systems and the growth and yield properties of FARO 52 rice except for the height of the rice plant where the model failed to be adequate with a $\mathrm{p}>0.05$. It was also observed that the explained variation for

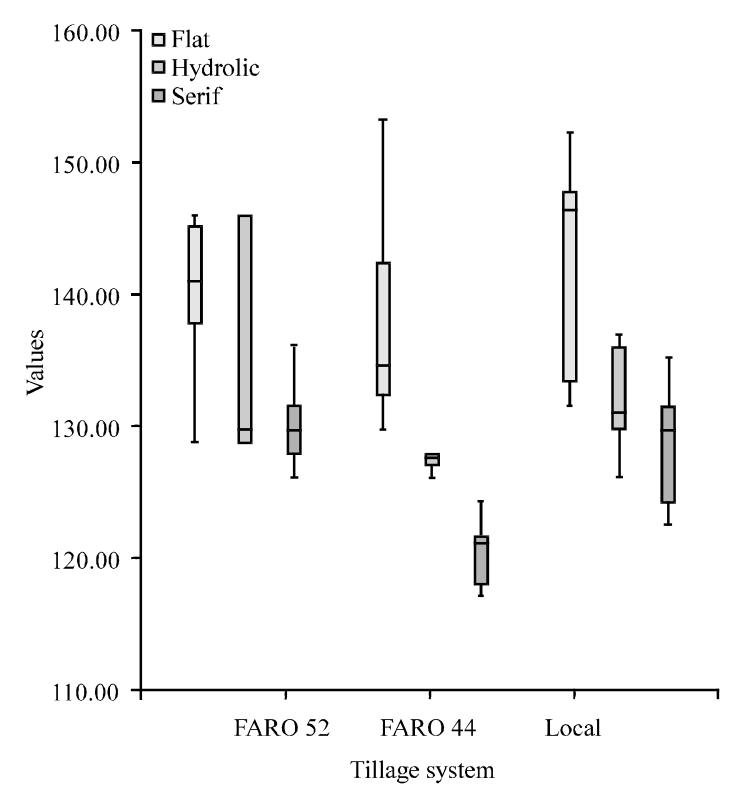

Fig. 3: Box plot of tillage systems effect on the days to mature of the three varieties of rice

FARO 52 rice was too small except for the panicle length that was able to explain $71.5 \%$ of the variations in the model.

For FARO 44 as shown in Table 4, a linear relationship which is statistically significant was established between tillage systems, the growth and yield properties. The explained variation for FARO 44 rice was a little high except for plant height where the model is capable of accounting for only $24.7 \%$ of the variations.

In Table 5 , for the number of tiller and panicle length, a linear relationship which is statistically significant could not be established between tillage systems, the growth 
Table 3: Linear relationship between the tillage systems, growth and yield of FARO 52

\begin{tabular}{|c|c|c|c|c|c|c|}
\hline \multirow[b]{2}{*}{ Properties } & \multirow[b]{2}{*}{$\mathrm{R}$} & \multirow[b]{2}{*}{$\mathrm{R}^{2}$} & \multirow[b]{2}{*}{ F-values } & \multirow[b]{2}{*}{ Models } & \multicolumn{2}{|c|}{ Coefficients } \\
\hline & & & & & $\alpha$ & $\beta$ \\
\hline Days to flower & 0.602 & 0.363 & 0.008 & $\mathrm{Y}=121-7.417 \mathrm{X}$ & 0.001 & 0.008 \\
\hline Days to maturity & 0.558 & 0.312 & 0.016 & $\mathrm{Y}=145.668-5.417 \mathrm{X}$ & 0.001 & 0.016 \\
\hline No. of tillers & 0.635 & 0.403 & 0.005 & $\mathrm{Y}=20.944-1.500 \mathrm{X}$ & 0.001 & 0.005 \\
\hline Panicle lenght & 0.846 & 0.715 & 0.000 & $\mathrm{Y}=9.556+4.333 \mathrm{X}$ & 0.001 & 0.000 \\
\hline Plant height & 0.257 & 0.066 & 0.304 & $\mathrm{Y}=114.309+2.969 \mathrm{X}$ & 0.001 & 0.304 \\
\hline Grain yield & 0.650 & 0.422 & 0.004 & $\mathrm{Y}=1.585+0.207 \mathrm{X}$ & 0.001 & 0.004 \\
\hline
\end{tabular}

Table 4: Linear relationship between the tillage systems, growth and yield of FARO 44

\begin{tabular}{|c|c|c|c|c|c|c|}
\hline \multirow[b]{2}{*}{ Properties } & \multirow[b]{2}{*}{$\mathrm{R}$} & \multirow[b]{2}{*}{$\mathrm{R}^{2}$} & \multirow[b]{2}{*}{ F-values } & \multirow[b]{2}{*}{ Models } & \multicolumn{2}{|c|}{ Coefficients } \\
\hline & & & & & $\alpha$ & $\beta$ \\
\hline Days to flower & 0.851 & 0.723 & 0.000 & $\mathrm{Y}=111.167-5.833 \mathrm{X}$ & 0.001 & 0.000 \\
\hline Days to maturity & 0.821 & 0.675 & 0.000 & $\mathrm{Y}=146.889-9.583 \mathrm{X}$ & 0.001 & 0.000 \\
\hline No. of tillers & 0.746 & 0.557 & 0.000 & $\mathrm{Y}=18.167-1.500 \mathrm{X}$ & 0.001 & 0.000 \\
\hline Panicle length & 0.842 & 0.709 & 0.000 & $\mathrm{Y}=12.378+3.629 \mathrm{X}$ & 0.001 & 0.000 \\
\hline Plant height & 0.497 & 0.247 & 0.036 & $\mathrm{Y}=86.226+9.253 \mathrm{X}$ & 0.001 & 0.036 \\
\hline Grain yield & 0.826 & 0.682 & 0.000 & $\mathrm{Y}=1.724+0.366 \mathrm{X}$ & $0.001 \mathrm{~s}$ & 0.000 \\
\hline
\end{tabular}

Table 5: Linear relationship between the tillage systems, growth and yield of local rice

\begin{tabular}{|c|c|c|c|c|c|c|}
\hline \multirow[b]{2}{*}{ Properties } & \multirow[b]{2}{*}{$\mathrm{R}$} & \multirow[b]{2}{*}{$\mathrm{R}^{2}$} & \multirow[b]{2}{*}{ F-values } & \multirow[b]{2}{*}{ Models } & \multicolumn{2}{|c|}{ Coefficients } \\
\hline & & & & & $\alpha$ & $\beta$ \\
\hline Days to flower & 0.866 & 0.751 & 0.001 & $\mathrm{Y}=128.389-10.500 \mathrm{X}$ & 0.001 & 0.001 \\
\hline Days to maturity & 0.702 & 0.492 & 0.001 & $\mathrm{Y}=150.000-7.833 \mathrm{X}$ & 0.001 & 0.001 \\
\hline No. of tillers & 0.039 & 0.001 & 0.879 & $\mathrm{Y}=19.278-0.083 \mathrm{X}$ & 0.001 & 0.879 \\
\hline Panicle length & 0.156 & 0.024 & 0.536 & $\mathrm{Y}=20.731-0.378 \mathrm{X}$ & 0.001 & 0.536 \\
\hline Plant height & 0.613 & 0.376 & 0.007 & $\mathrm{Y}=132.288+7.363 \mathrm{X}$ & 0.001 & 0.007 \\
\hline Grain yield & 0.703 & 0.494 & 0.001 & $\mathrm{Y}=1.072+0.303 \mathrm{X}$ & 0.001 & 0.001 \\
\hline
\end{tabular}

$\mathrm{R}=$ Correlation, $\mathrm{R}^{2}=$ Explained variation, $\mathrm{F}=\mathrm{p}$-value for model adequacy, Coefficients = $\mathrm{p}$-values for showing the significance of the model's coefficient

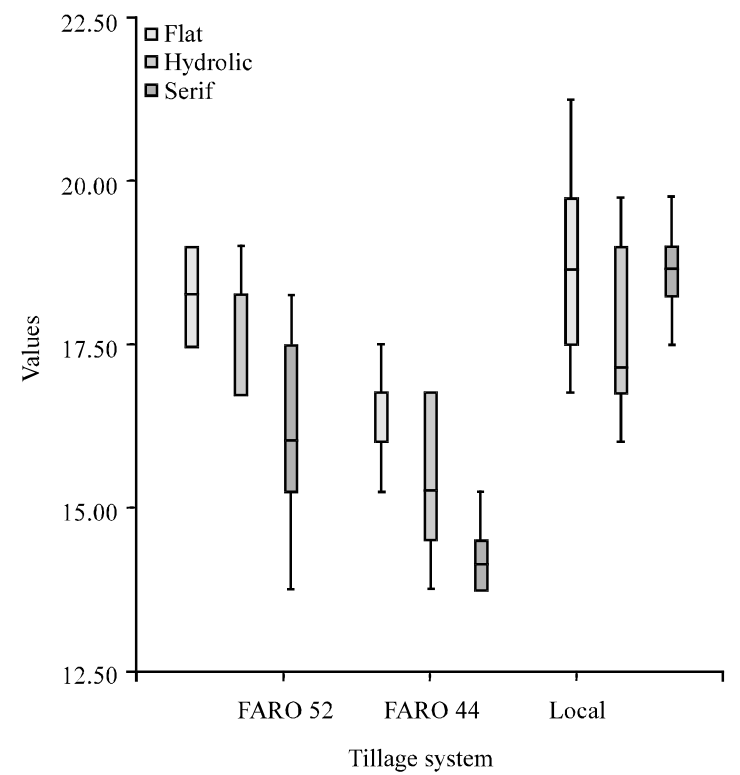

Fig. 4: Box plot of tillage systems effect on the no tillage of the three varieties of rice

and yield properties of local rice. This is because of the insignificant value of $\mathrm{F}$ at $\mathrm{p}<0.05$ causing the linear model to be inadequate. This can also be observed from the

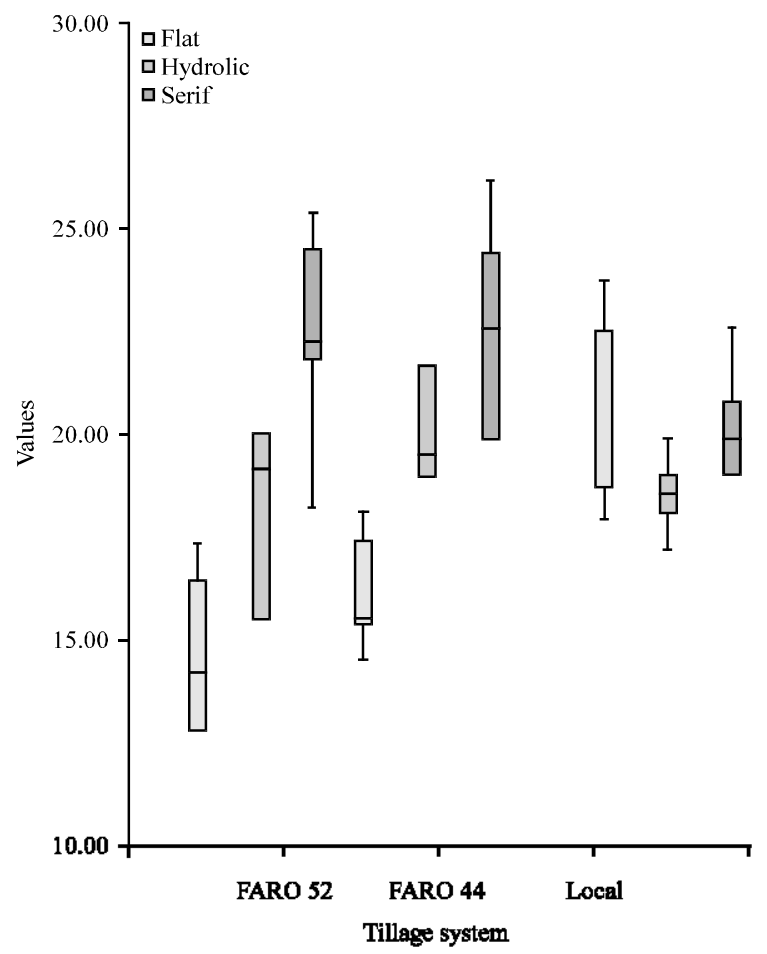

Fig. 5: Box plot of tillage systems effect on the pannicle length of the three varieties of rice 


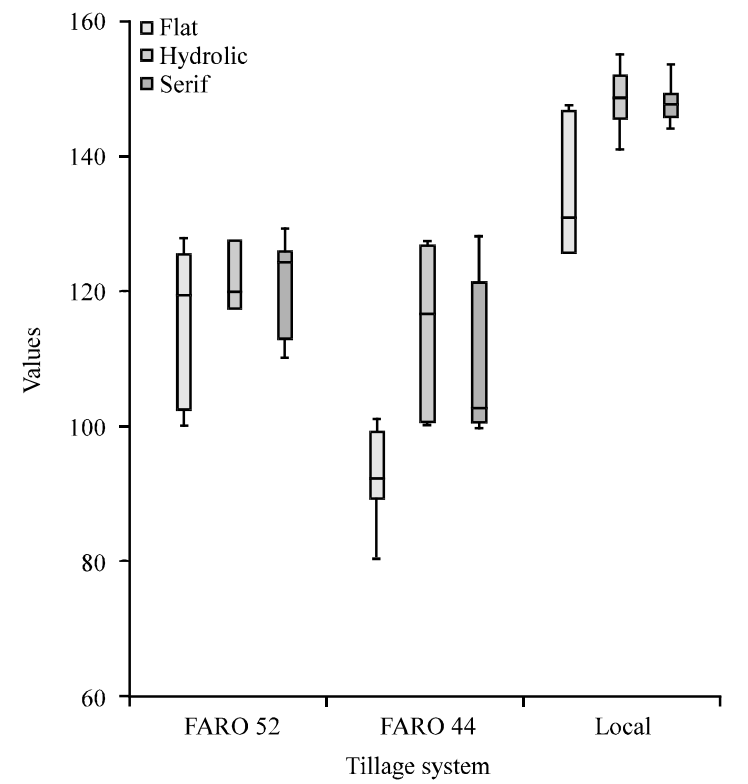

Fig. 6: Box plot of tillage systems effect on the plant height of the three varieties of rice

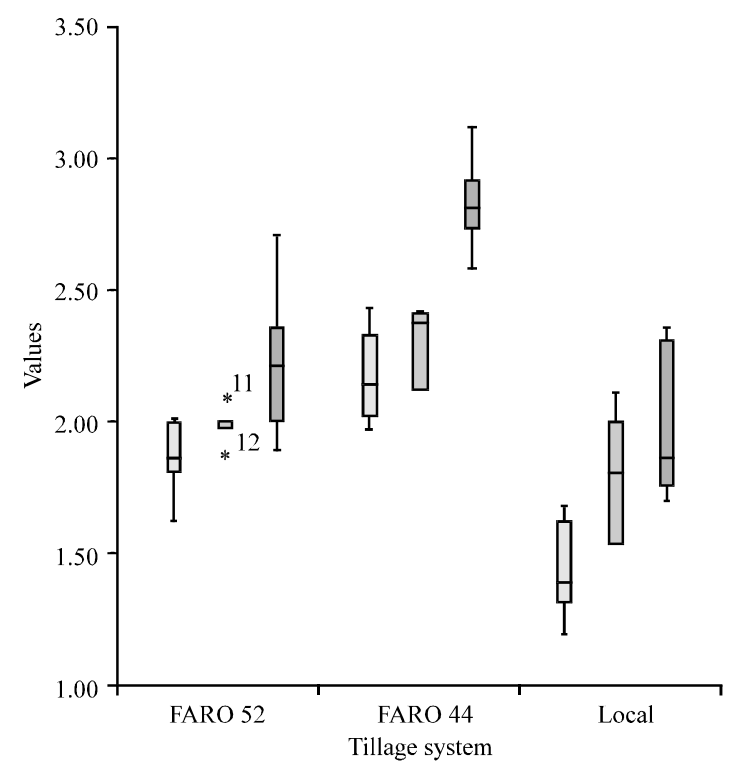

Fig. 7: Box plot of tillage systems effect on the grain yield of the three varieties of rice

insignificant value of $\beta$ at $p<0.05$. It was also noticed that the explained variation for local rice was too small except for the days to flower where the model was capable of explaining $75.1 \%$ of the variations.

\section{CONCLUSION}

The research was undertaken to help rice growers and stakeholder in rice farming to appreciate the interaction effect that tillage practice and varieties have on the yield performance and other plants developmental performance and how these are correlated. The knowledge is to guide fabricators of agricultural equipment in precision decisions and planning towards efficient agricultural machinery development. This will make energy and resources to be tailored towards profitable technique for rice production towards a self-sufficient output. Results obtained showed investigated parameters has an effect and linear relationships on the agronomic characteristics of rice varieties under lowland plantation.

\section{ACKNOWLEDGEMENTS}

We sincerely acknowledge the critical observations, comments and corrections of esteemed reviewers whose input improved the execution of this research considerably. We also thank the editor and the anonymous reviewers for their valuable comments. Our sincere appreciation also to the Management of Landmark University for making the fund available for the publication of this research.

\section{REFERENCES}

Adekalu, K.O. and D.A. Okunade, 2008. Evaluation of crop yield models for cowpea in Nigeria. Irrig. Sci., 26: 385-393.

Ajala, A.S. and A. Gana, 2015. Analysis of challenges facing rice processing in Nigeria. J. Food Process., Vol. 2015. 10.1155/2015/893673

Alhassan, E.A., A.D. Adewumi and B. Okpodjah, 2018. Development of a self-propelled multi-crop two rows precision planter: A new design concept for the metering mechanism. Intl. J. Mech. Eng. Technol., 9: 349-358.

Aremu, C.O., E.A. Alhassan, A.J. Asaleye, E. Alori, S. Ige and G. Nayan, 2018. Effect of varietal and tillage methods on agronomic and yield characters of rice (Oryza sativa L). Int. J. Civil Eng. Technol., 9: 590-600.

Donohue, R.J., R.A. Lawes, G. Mata, D. Gobbett and J. Ouzman, 2018. Towards a national, remote-sensing-based model for predicting field-scale crop yield. Field Crops Res., 227: 79-90.

El-Sharkawy, M.A., 2011. Overview: Early history of crop growth and photosynthesis modeling. Biosystems, 103: 205-211.

Gottschalk, P., A. Luttger, S. Huang, T. Leppelt and F. Wechsung, 2018. Evaluation of crop yield simulations of an Eco-hydrological model at different scales for Germany. Field Crops Res., 228: 48-59. 
Gupta, J.P. and S. Kumar, 2001. Status of power tiller use in Bihar-A case study in Nalanda District. Agric. Mechanization Asia Afr. Latin Am., 32: 19-22.

Ingle, S.T., S.N. Patil, P.M. Kolhe, N.P. Marathe and N.R. Kachate, 2018. Evaluation of agricultural soil quality in Khandesh Region of Maharashtra, India. Nat. Environ. Pollut. Technol., 17: 1147-1160.

Kemi, A.O., 2018. Challenges of rice production in Nigeria: A case study of Kogi State. Food Sci. Qual. Manage., 74: 14-17.

Merem, E.C., Y. Twumasi, J. Wesley, P. Isokpehi and M. Shenge et al., 2017. Analyzing rice production issues in the Niger State area of Nigeria's middle belt. Food Public Health, 7: 7-22.

Meshesha, D.T. and M. Abeje, 2018. Developing crop yield forecasting models for four major Ethiopian agricultural commodities. Remote Sens. Appl. Soc. Environ., 11: 83-93.

Oladapo, O.J. and E.O. Omidiora, 2014. A genetic algorithm approach to maximize crop yields and sustain soil fertility. Net J. Agric. Sci., 2: 94-103.
Olaye, A.B., J. Moreira, S.K. Amponsah, S. Okurut and D.J. Hounhouigan, 2016. Effect of threshing drum speed and crop weight on paddy grain quality in Axial-Flow Thresher (ASi). J. Multi. Eng. Sci. Technol., 3: 3159-3721.

Oteng-Darko, P., S. Yeboah, S.N.T. Addy, S. Amponsah and E.O. Danquah, 2013. Crop modeling: A tool for agricultural research-A review. E3 J. Agric. Res. Dev., 2: $1-6$.

Ramirez-Villegas, J., A.K. Koehler and A.J. Challinor, 2017. Assessing uncertainty and complexity in regional-scale crop model simulations. Eur. J. Agron., 88: 84-95.

Rowhani, P., D.B. Lobell, M. Linderman and N. Ramankutty, 2011. Climate variability and crop production in Tanzania. Agric. Forest Meteorol., 151: 449-460.

Safa, M., 2011. Determination and modelling of energy consumption in wheat production using neural networks. Ph.D Thesis, Department of Environmental Management, Society and Design, Lincoln University, Lincoln, New Zealand. 